\title{
Growth Yields and Respiratory Efficiency of Acinetobacter calcoaceticus
}

\author{
By CHARLES A. FEWSON \\ Department of Biochemistry, University of Glasgow, Glasgow G12 8QQ, Scotland, UK
}

(Received 7 September 1984)

\begin{abstract}
Acinetobacter calcoaceticus NCIB 8250 was grown in batch culture on 46 separate sources of carbon + energy and the molar growth yields were measured. The organism was also grown in continuous culture on L-mandelate, phenylglyoxylate and succinate and the results used to calculate maximum molar growth yields. The elemental composition of the bacteria was determined. Growth equations for each substrate were constructed so that the amount of oxygen consumed per mol of substrate could be calculated. Growth yields on oxygen $\left(Y_{\mathrm{O}_{2}}\right)$ were then estimated. The $\mathrm{Y}_{\mathrm{O}_{2}}$ values were low [averaging about $19 \mathrm{~g}$ dry wt $\left(\mathrm{mol} \mathrm{O}_{2}\right)^{-1}$ ]. The most likely explanation for the low yields is that the effective $\mathrm{P} / \mathrm{O}$ ratio is only about one, although there are probably at least two sites of oxidative phosphorylation.
\end{abstract}

\section{INTRODUCTION}

Acinetobacter calcoaceticus is an obligate aerobe and most strains are metabolically versatile (Baumann et al., 1968). It is common in natural environments (Baumann, 1968) and has been identified as a member of a number of microbial communities (Wilkinson et al., 1974; Slater \& Bull, 1982). Several possible industrial applications of $A$. calcoaceticus have been investigated (Du Preez et al., 1981).

Hardy \& Dawes (1985) found rather low values for maximum molar growth yields on oxygen and succinate when $A$. calcoaceticus NCIB 8250 was grown in continuous culture under conditions of carbon or oxygen limitation. I have measured yields of the same strain on 46 substrates in batch cultures. Three of the compounds, including succinate, were also used as substrates in continuous cultures in order to compare the results with those of Hardy \& Dawes (1985) and to check the calculations based on measurements of yields in batch cultures. The results show that the low yields found by Hardy \& Dawes (1985) were not simply a consequence of some peculiarity of growth on succinate and indicate that their conclusions apply to growth of $A$. calcoaceticus on a wide range of compounds. In addition, the estimates of yields should serve as a basis for evaluating potential industrial uses of $A$. calcoaceticus as well as for quantifying the contribution made to the microbial communities of which it is a member.

\section{METHODS}

Organism. Acinetobacter calcoaceticus NCIB 8250 was obtained from the National Collection of Industrial Bacteria, Aberdeen, UK. Stock cultures were maintained in Oxoid cooked meat medium stored at $4{ }^{\circ} \mathrm{C}$. Subcultures were made into Oxoid nutrient broth at intervals of approximately 2 months and were also kept at $4{ }^{\circ} \mathrm{C}$. Inocula used in growth experiments were produced by a further subculture into nutrient broth and incubated at $30{ }^{\circ} \mathrm{C}$ for 17 to $24 \mathrm{~h}$ immediately before use.

Measurements of molar growth yields in batch cultures. Media contained an appropriate amount of carbon source, $1 \mathrm{~g}\left(\mathrm{NH}_{4}\right)_{2} \mathrm{SO}_{4}$ and $2 \mathrm{~g} \mathrm{KH}_{2} \mathrm{PO}_{4}$, adjusted to $\mathrm{pH} 7.0$ and made to 1 litre. All substrates were tested at four concentrations with the highest concentration chosen to produce a yield equivalent to an optical density at $500 \mathrm{~nm}$ of between 0.4 and 0.7 . Each experiment contained controls without added carbon source. Media were dispensed in $50 \mathrm{ml}$ amounts in $250 \mathrm{ml}$ Erlenmeyer conical flasks plugged with disposable foam bungs and autoclaved at $109^{\circ} \mathrm{C}$. Heat-labile compounds were adjusted to $\mathrm{pH} 7.0$ and then sterilized by filtration through Millipore filters $\left(0 \cdot 22 \mu \mathrm{m}\right.$ pore size) before addition to sterile solutions of $\left(\mathrm{NH}_{4}\right)_{2} \mathrm{SO}_{4}$ and $\mathrm{KH}_{2} \mathrm{PO}_{4}$. Inocula $(0 \cdot 1 \mathrm{ml}$ of a nutrient 
broth culture) and $1.0 \mathrm{ml}$ of sterile $2 \%(\mathrm{w} / \mathrm{v}) \mathrm{MgSO}_{4} .7 \mathrm{H}_{2} \mathrm{O}$ were added to the flasks, which were then placed on a rotary shaker ( $\mathrm{LH}$ Engineering, Ltd) and shaken at $30^{\circ} \mathrm{C}$ at about 180 oscillations $\mathrm{min}^{-1}$. Growth was measured (usually at about $17,24,48$ and $72 \mathrm{~h}$ ) by taking samples aseptically and determining the optical density at $500 \mathrm{~nm}$ in a Spectronic 20 colorimeter using round tubes of internal diameter $11.7 \mathrm{~mm}$. The same colorimeter was used throughout these experiments and the relationship between $\mathrm{OD}_{500}$ and bacterial concentration was linear up to about 0.4 ; suspensions which were more concentrated than this were diluted with basal medium before measurement of the $\mathrm{OD}_{500}$. Experiments with bacteria grown on a range of substrates showed that a suspension with an $\mathrm{OD}_{500}$ equivalent to 1.0 contained $352 \mu \mathrm{g}_{\text {dry }} \mathrm{wt} \mathrm{ml}^{-1}$ (the standard deviation was $17 \mu \mathrm{g}$ dry wt $\mathrm{ml}^{-1}$ for 19 batches of bacteria, each assayed in duplicate or triplicate). Molar growth yields $\left[Y_{\text {substrate }} ; \mathrm{g}\right.$ dry wt (mol substrate $)^{-1}$ ] were calculated as the maximum slopes of graphs of yield ( $\mu \mathrm{g}$ dry $\mathrm{wt} \mathrm{ml}^{-1}$ at whichever time of sampling gave the highest yield) against substrate concentration (mM). The number of independent experiments with each substrate is listed in Table 1.

Measurements of maximum molar growth yields in continuous cultures. Bacteria were grown in a chemostat similar to that described by Baker (1968). The medium was the same as that used for batch cultures except that it also contained a trace metal mixture (Beggs \& Fewson, 1977). The culture volume was about $600 \mathrm{ml}$, the temperature $30{ }^{\circ} \mathrm{C}$ and the air flow rate $200 \mathrm{ml} \mathrm{min} \mathrm{m}^{-1}$. Succinate $(3.5 \mathrm{~mm}$ in the reservoir), L-mandelate $(1.5 \mathrm{mM})$ or phenylglyoxylate $(1.5 \mathrm{mM})$ were used as the limiting substrates. Yield was dependent on the concentration of carbon source but was not affected by doubling the concentration of $\left(\mathrm{NH}_{4}\right)_{2} \mathrm{SO}_{4}$ or $\mathrm{KH}_{2} \mathrm{PO}_{4}$. At least 10 replacement volumes of medium were added before each sample was taken for determination of $\mathrm{OD}_{500}$ in a $\mathrm{Pye}$ Unicam SP800 spectrophotometer using $1 \mathrm{~cm}$ cuvettes. Samples were taken at growth rates between about 0.12 and $0.6 \mathrm{~h}^{-1}$. Yields $\left(\mu \mathrm{g}\right.$ dry wt $\left.\mathrm{ml}^{-1}\right)$ were calculated by reference to standard curves of $\mathrm{OD}_{500}$ against bacterial dry weight $\left(\mu \mathrm{g} \mathrm{ml}^{-1}\right)$. These curves varied from instrument to instrument but a bacterial suspension with an $\mathrm{OD}_{50 \mathrm{~N}}$ equivalent to 1.0 contained between 250 and $300 \mu \mathrm{g}$ dry wt $\mathrm{ml}^{-1}$. Maximum molar growth yields [ $Y_{\text {substrate }}^{\max } ; \mathrm{g}$ dry wt (mol substrate) $\left.)^{-1}\right]$ and maintenance coefficients $\left[m ; m m o l\right.$ substrate $\left.(\mathrm{g} \text { dry wt})^{-1} \mathrm{~h}^{-1}\right]$ were derived from the intercepts and slopes respectively of graphs of reciprocal of yield [mol substrate ( $\mathrm{g}$ dry $\mathrm{wt})^{-1}$ ] against reciprocal of growth rate (h) (Pirt, 1965). These graphs were all straight lines (correlation coefficients $>0 \cdot 9$ ). Values listed in Table 1 are means from independent duplicate chemostat experiments.

Measurements of growth rates. The procedure was the same as that used previously (Fewson, 1967) except that the optical density was measured at $500 \mathrm{~nm}$.

Elemental composition. Washed and dried bacteria were analysed as follows: carbon, hydrogen and nitrogen by Dr G. Weiler and Dr F. B. Strauss (latterly Dr F. B. Strauss; Oxford), Butterworth Microanalytical Consultancy Ltd (Teddington) and the Microanalysis Laboratory, Department of Chemistry, University of Glasgow; phosphorus and sulphur by Dr G. Weiler and Dr F. B. Strauss; oxygen by Butterworth Microanalytical Consultancy Ltd; calcium, iron and magnesium by Dr M. R. Moore (Department of Materia Medica, Stobhill Hospital, Glasgow) using colorimetric methods; chlorine, copper, manganese, potassium, sodium and zinc by $\mathrm{Dr}$ F. C. Gillespie (Western Regional Hospital Board Department of Clinical Physics and Bio-Engineering, Glasgow) using neutron activation analysis.

\section{RESULTS AND DISCUSSION}

\section{Elemental composition}

Values for each element are listed as the mean percentage of dry weight \pm SD with the number of different batches of bacteria analysed (mostly in duplicate) given in parentheses: C, $47.64 \pm 1.40$ (23); H, 6.64 \pm 0.21 (23); N, 12.32 \pm 1.47 (23); $\mathrm{O}$ (which in other studies has usually been estimated by difference), $28.93 \pm 0.90$ (10); P, $2.11 \pm 0.35$ (15); S, $1.75 \pm 0.31$ (14). These results were obtained for bacteria grown in batch cultures in which growth had been limited by the carbon + energy source (usually succinate) and there was no discernible trend of differences amongst bacteria grown on different carbon sources. Minor elements showed more variation, possibly as a consequence of different growth rates or the choice of washing procedure (see e.g. Tempest et al., 1966). The ranges were (percentage of dry weight): $\mathrm{K}, 0.3$ to $1.5 ; \mathrm{Mg}, 0.1$ to $0.4 ; \mathrm{Cl}, 0.05$ to $0.8 ; \mathrm{Na}, 0.07$ to $0.19 ; \mathrm{Ca}, \mathrm{Fe}, \mathrm{Mn}, \mathrm{Cu}$ and $\mathrm{Zn}$ (total), 0.021 to 0.042 .

\section{Growth in batch cultures}

A. calcoaceticus NCIB 8250 can grow on over one hundred compounds as sole sources of carbon + energy (Fewson, 1967; Baumann et al., 1968). The present work was restricted to 46 compounds (Table 1) which satisfied the following criteria: $(a)$ they could be obtained in sufficiently pure form; $(b)$ they were not unstable or too volatile; $(c)$ they were soluble enough to 
give adequate concentrations in the medium; $(d)$ they supported fairly rapid growth (mean generation times generally $1 \mathrm{~h}$ or less, and not more than about $3 \mathrm{~h}$ ).

In preliminary experiments the conditions were shown to be optimal with respect to: volume of medium in the growth flasks, speed of shaking, temperature, $\mathrm{pH}$ value.

If the nitrogen source in the medium was nitrate $\left(1 \mathrm{~g} \mathrm{KNO}_{3} \mathrm{l}^{-1}\right)$ rather than ammonia the carbon growth yield was lowered by about a quarter (19 to $34 \%$ ) for all the substrates tested (acetate, azelaate, fumarate, 2-oxoglutarate, L-malate, phenylacetate, phenylglyoxylate and succinate). This is consistent with the theoretical estimates of Stouthamer (1979). The effect on growth rate was rather more varied; for instance growth on 2-oxoglutarate was hardly affected (mean generation times of 97 to $114 \mathrm{~min}$ on either nitrate or ammonia in several experiments) whereas growth on succinate/nitrate (mean generation time 92 to $99 \mathrm{~min}$ ) was much slower than that on succinate/ammonia ( 50 to $56 \mathrm{~min}$ ). These results confirm that supply of reductant limited growth in these experiments.

\section{Growth in continuous cultures}

The maximum growth yield of $41 \cdot 1 \mathrm{~g}$ dry wt (mol succinate) $)^{-1}$ (Table 1 ) was close to the values

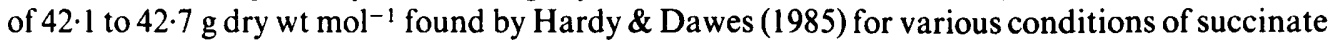
or oxygen limitation.

Maintenance coefficients on L-mandelate, phenylglyoxylate and succinate were $0 \cdot 34,0.66$ and $0.67 \mathrm{mmol}$ substrate $(\mathrm{g} \text { dry } \mathrm{wt})^{-1} \mathrm{~h}^{-1}$ respectively.

\section{Comparison of batch and continuous cultures}

Yields in batch cultures are often felt to be inadequate as the basis for calculations of respiratory efficiency and other theoretical aspects of growth yields. However, comparison of the values in Table 1 for mandelate or phenylglyoxylate (which might be suspected to give very different yields in batch and continuous cultures because they support non-exponential growth in batch cultures; Cook et al., 1975) or succinate revealed a maximum discrepancy of about $13 \%$ between the batch and continuous cultures. This difference was presumably caused by maintenance requirements (Pirt, 1965, 1982; but see van Verseveld et al., 1984). In addition, Jones et al. (1973) determined the maximum molar growth yield of strain NCIB 8250 growing on phenol in continuous culture and obtained a value very close to the yield found for batch culture in the present work (Table 1). These sorts of differences between molar growth yields and maximum molar growth yields are insufficient seriously to alter the final conclusions. More important, studies confined to continuous cultures are so time-consuming that they cannot easily be extended to a wide range of substrates and are therefore in danger of producing nonrepresentative results.

\section{Calculation of oxygen uptake during growth}

The values for growth yields, together with the elemental composition of the bacteria, allowed equations to be calculated for growth on each of the substrates. Thus for the yield observed by Hardy \& Dawes (1985) for continuous culture on succinate the equation was:

$$
\mathrm{C}_{4} \mathrm{H}_{6} \mathrm{O}_{4}+1.795 \mathrm{O}_{2}+0.37 \mathrm{NH}_{3} \rightarrow \mathrm{C}_{1.67} \mathrm{H}_{2.77} \mathrm{O}_{0.76} \mathrm{~N}_{0.37}+2.33 \mathrm{CO}_{2}+2.17 \mathrm{H}_{2} \mathrm{O}
$$

In the case of aromatic compounds an allowance was made for oxygenative reactions because presumably they cannot lead to oxidative phosphorylation (Dagley, 1978). For continuous culture on phenylglyoxylate the equation was therefore:

$$
\begin{gathered}
\mathrm{C}_{8} \mathrm{H}_{6} \mathrm{O}_{3}+2 \mathrm{O}_{2} \text { (oxygenation) }+3.30 \mathrm{O}_{2} \text { (respiration) }+0.58 \mathrm{NH}_{3} \rightarrow \\
\mathrm{C}_{2.64} \mathrm{H}_{4.38} \mathrm{O}_{1.20} \mathrm{~N}_{0.58}+5.36 \mathrm{CO}_{2}+1.68 \mathrm{H}_{2} \mathrm{O}
\end{gathered}
$$

Ammonia would be produced, not consumed, when amino acids and related compounds were used as substrates. So for growth on glutamate, where aspartase appears to be responsible for ammonia formation (A. C. Borthwick, unpublished results):

$$
\mathrm{C}_{5} \mathrm{H}_{9} \mathrm{O}_{4} \mathrm{~N}+2.39 \mathrm{O}_{2} \rightarrow \mathrm{C}_{2.07} \mathrm{H}_{3 \cdot 43} \mathrm{O}_{0.94} \mathrm{~N}_{0.46}+2.93 \mathrm{CO}_{2}+1.98 \mathrm{H}_{2} \mathrm{O}+0.54 \mathrm{NH}_{3}
$$




\section{Table 1. Growth yields and calculated $Y_{\mathrm{O}_{2}}$ values for $A$. calcoaceticus}

Molar growth yields of strain NCIB 8250 were measured for batch cultures as described in Methods and then the $Y_{\mathrm{O}_{2}}$ values calculated as explained in the text. Maximum molar growth yields (shown in bold type) were determined using continuous cultures; results for strain NCIB 8250 growing on Lmandelate, phenylglyoxylate and succinate were obtained in the present work and the other values are taken from the papers listed in the footnotes. Calculations were made using the maximum appropriate number of significant figures. Numbers of atoms of $O$ taken up and values for $Y_{\mathrm{O}_{2}}$ were rounded off to two places of decimals for presentation.

\begin{tabular}{|c|c|c|c|c|c|c|}
\hline \multirow[b]{2}{*}{ Substrate } & \multicolumn{3}{|c|}{ Growth yield } & \multirow[b]{2}{*}{$\begin{array}{c}\text { Calculated } \\
\text { oxygen uptake } \\
{\left[\text { mol } \mathrm{O}_{2}(\mathrm{~mol}\right.} \\
\left.\text { substrate })^{-1}\right]\end{array}$} & \multirow[b]{2}{*}{$\begin{array}{c}\text { Oxygen required } \\
\text { for oxygenation } \\
{\left[\mathrm{mol} \mathrm{O} \mathrm{O}_{2}\right.} \\
\text { (mol substrate) }^{-1} \text { ] }\end{array}$} & \multirow[b]{2}{*}{$\begin{array}{c}\text { Calculated } \\
Y_{\mathrm{O}_{2}} \\
\text { [g dry wt } \\
\left(\mathrm{mol} \mathrm{O}_{2}\right)^{-1}\end{array}$} \\
\hline & $\begin{array}{c}\text { Mean } \\
\text { [g dry wt } \\
{\text { (mol substrate })^{-1}}^{-1}\end{array}$ & $\begin{array}{c}\text { No. of } \\
\text { ] experiments }\end{array}$ & $\begin{array}{c}\text { SEM } \\
\text { as } \% \\
\text { of mean }\end{array}$ & & & \\
\hline $\begin{array}{l}\text { cetate } \\
\text { cetate* }\end{array}$ & $20 \cdot 1$ & 7 & $2 \cdot 9$ & $1 \cdot 185$ & & 16.96 \\
\hline dipate & $\begin{array}{l}30 \cdot 8 \\
70 \cdot 4\end{array}$ & 3 & & $\begin{array}{l}0.755 \\
3.65\end{array}$ & & $\begin{array}{r}40 \cdot 80 \\
10.28\end{array}$ \\
\hline Alanine & 28.9 & $\begin{array}{l}3 \\
3\end{array}$ & $\begin{array}{l}2 \cdot 4 \\
4 \cdot 3\end{array}$ & 1.825 & & $\begin{array}{l}19 \cdot 28 \\
15 \cdot 83\end{array}$ \\
\hline$\beta$-Alanine & .28 .9 & 3 & 0 & 1.825 & & $15 \cdot 83$ \\
\hline Asparagine & 29.9 & 3 & 0.5 & $2 \cdot 035$ & & $14 \cdot 70$ \\
\hline Aspartate & $30 \cdot 2$ & 5 & $5 \cdot 1$ & $1 \cdot 78$ & & 16.96 \\
\hline zelaate & $102 \cdot 1$ & 4 & $2 \cdot 1$ & 6.87 & & $14 \cdot 86$ \\
\hline zaldehyde & $72 \cdot 5$ & 4 & $2 \cdot 0$ & $5 \cdot 06$ & 2 & $23 \cdot 70$ \\
\hline zoate & $62 \cdot 7$ & 9 & $4 \cdot 6$ & 4.955 & 2 & $21 \cdot 22$ \\
\hline nzyl alcohol & 79.9 & 6 & $4 \cdot 6$ & $5 \cdot 26$ & 2 & $24 \cdot 50$ \\
\hline atane 2,3-diol & 53.9 & 3 & 1.4 & $3 \cdot 31$ & & $16 \cdot 28$ \\
\hline styrate & 48.9 & 7 & $2 \cdot 0$ & $3 \cdot 02$ & & $16 \cdot 20$ \\
\hline proate & $81 \cdot 7$ & 3 & $2 \cdot 3$ & $4 \cdot 695$ & & $17 \cdot 40$ \\
\hline tonate & 38.4 & 3 & $2 \cdot 6$ & 2.95 & & 13.02 \\
\hline anol & $29 \cdot 2$ & 5 & $3 \cdot 3$ & 1.82 & & $16 \cdot 04$ \\
\hline anol* & 38.9 & & & 1.425 & & $27 \cdot 30$ \\
\hline hanol $†$ & 35.7 & & & 1.55 & & 23.04 \\
\hline umarate & $33 \cdot 8$ & 12 & 1.9 & 1.635 & & $20 \cdot 68$ \\
\hline lutaconate & $45 \cdot 6$ & 5 & 1.6 & $2 \cdot 65$ & & $17 \cdot 20$ \\
\hline Glutamate & $52 \cdot 1$ & 6 & $2 \cdot 2$ & $2 \cdot 39$ & & $21 \cdot 80$ \\
\hline Glutamine & $50 \cdot 3$ & 2 & 0.2 & $2 \cdot 71$ & & $18 \cdot 56$ \\
\hline tarate & $51 \cdot 7$ & 3 & $3 \cdot 3$ & 2.90 & & $17 \cdot 82$ \\
\hline toate & $104 \cdot 9$ & 3 & $3 \cdot 1$ & $5 \cdot 255$ & & 19.96 \\
\hline Hexenoate & $86 \cdot 2$ & 5 & $5 \cdot 3$ & $4 \cdot 01$ & & $21 \cdot 50$ \\
\hline Histidine & 44.0 & 5 & 1.9 & $3 \cdot 215$ & & 13.68 \\
\hline $\begin{array}{l}\text { Hydroxybenz- } \\
\text { aldehyde }\end{array}$ & $68 \cdot 3$ & 1 & & 4.73 & 2 & $25 \cdot 02$ \\
\hline $\begin{array}{l}\text { Hydroxybenzyl } \\
\text { alcohol }\end{array}$ & $69 \cdot 3$ & 1 & & $5 \cdot 19$ & 2 & $21 \cdot 72$ \\
\hline $\begin{array}{l}\text { Hydroxybenzyl } \\
\text { alcohol }\end{array}$ & $72 \cdot 9$ & 1 & & 5.05 & 2 & 23.90 \\
\hline Hydroxybenzoate & $57 \cdot 7$ & 3 & $4 \cdot 0$ & $4 \cdot 665$ & 2 & $21 \cdot 65$ \\
\hline L-Lactate & $31 \cdot 3$ & 5 & 1.6 & 1.74 & & 17.98 \\
\hline L-Lactate $\ddagger$ & 35.8 & & & 1.555 & & 23.02 \\
\hline Malate & $31 \cdot 7$ & 17 & $2 \cdot 5$ & 1.715 & & $18 \cdot 48$ \\
\hline Mandelate & 64.8 & 44 & $1 \cdot 0$ & $5 \cdot 875$ & 2 & $16 \cdot 72$ \\
\hline Mandelate & $70 \cdot 6$ & & & $5 \cdot 645$ & 2 & $19 \cdot 36$ \\
\hline Oxoadipate & $62 \cdot 3$ & 3 & $9 \cdot 1$ & 2.985 & & $20 \cdot 88$ \\
\hline xoglutarate & $46 \cdot 5$ & 7 & 1.4 & $2 \cdot 125$ & & $21 \cdot 88$ \\
\hline nenol & $56 \cdot 0$ & 3 & $3 \cdot 8$ & $4 \cdot 73$ & 2 & 20.52 \\
\hline nolş & 55.5 & & & $4 \cdot 755$ & 2 & $20 \cdot 14$ \\
\hline nylacetate & 93.6 & 4 & 1.9 & $5 \cdot 21$ & 2 & $29 \cdot 16$ \\
\hline nylglyoxylate & $65 \cdot 8$ & 9 & 4.5 & $5 \cdot 34$ & 2 & $19 \cdot 70$ \\
\hline nylglyoxylate & $66 \cdot 5$ & & & $5 \cdot 30$ & 2 & $20 \cdot 15$ \\
\hline elate & $75 \cdot 0$ & 3 & $1 \cdot 7$ & 4.97 & & $15 \cdot 09$ \\
\hline oline & $53 \cdot 2$ & 4 & $1 \cdot 2$ & $3 \cdot 35$ & & $15 \cdot 88$ \\
\hline ionate & $31 \cdot 0$ & 6 & $1 \cdot 3$ & $2 \cdot 245$ & & 13.80 \\
\hline ylate & $58 \cdot 1$ & 3 & $2 \cdot 7$ & 4.65 & 2 & 21.92 \\
\hline cate & $137 \cdot 3$ & 3 & $2 \cdot 1$ & 6.935 & & 19.80 \\
\hline
\end{tabular}


Table 1. Continued.

\begin{tabular}{|c|c|c|c|c|c|c|}
\hline \multirow[b]{2}{*}{ Substrate } & \multicolumn{3}{|c|}{ Growth yield } & \multirow[b]{2}{*}{$\begin{array}{c}\text { Calculated } \\
\text { oxygen uptake } \\
{\left[\mathrm{mol} \mathrm{O}_{2}(\mathrm{~mol}\right.} \\
\text { substrate })^{-1} \text { ] }\end{array}$} & \multirow[b]{2}{*}{$\begin{array}{c}\text { Oxygen required } \\
\text { for oxygenation } \\
{\left[\text { mol } \mathrm{O}_{2}\right.} \\
\left.\text { (mol substrate) }^{-1}\right]\end{array}$} & \multirow[b]{2}{*}{$\begin{array}{c}\text { Calculated } \\
Y_{\mathrm{O}_{2}} \\
{[\mathrm{~g} \mathrm{dry} \mathrm{wt}} \\
\left.\left(\mathrm{mol} \mathrm{O}_{2}\right)^{-1}\right]\end{array}$} \\
\hline & $\begin{array}{c}\text { Mean } \\
\text { [g dry wt } \\
{\left.\text { (mol substrate })^{-1}\right]}^{\text {(mol }}\end{array}$ & $\begin{array}{c}\text { No. of } \\
\text { experiments }\end{array}$ & $\begin{array}{c}\text { SEM } \\
\text { as } \% \\
\text { of mean }\end{array}$ & & & \\
\hline L-Serine & $21 \cdot 5$ & 2 & 0 & 1.635 & & $13 \cdot 15$ \\
\hline D-Serine & $22 \cdot 9$ & 1 & & 1.57 & & $14 \cdot 58$ \\
\hline Succinate & 35.9 & 18 & $2 \cdot 0$ & 2.055 & & $17 \cdot 46$ \\
\hline Succinate & $41 \cdot 1$ & & & 1.835 & & $22 \cdot 40$ \\
\hline Succinate & $42 \cdot 1$ & & & 1.795 & & $23 \cdot 46$ \\
\hline L-Tyrosine & $90 \cdot 5$ & 3 & $1 \cdot 2$ & $5 \cdot 84$ & 2 & 23.56 \\
\hline Valerate & $64 \cdot 4$ & 3 & $7 \cdot 1$ & 3.90 & & $16 \cdot 52$ \\
\hline Vanillate & $58 \cdot 8$ & 3 & $2 \cdot 9$ & 5.625 & 2 & $16 \cdot 22$ \\
\hline
\end{tabular}

Table 2. Comparison of the calculated amounts of $\mathrm{O}_{2}$ uptake with the values obtained by measuring respiration

The amounts of $\mathrm{O}_{2}$ uptake calculated from growth experiments were taken from Table 1 . Experimental stoichiometries of $\mathrm{O}_{2}$ uptake were derived from measurements of respiration in the Warburg apparatus in the experiments described by Kennedy \& Fewson (1968). Values are given as means \pm SD with the number of experiments in parentheses.

\begin{tabular}{lcc}
\multicolumn{1}{c}{ Substrate } & $\begin{array}{c}\mathrm{O}_{2} \text { uptake calculated } \\
\text { from growth experiments } \\
\text { [mol } \mathrm{O}_{2}(\mathrm{~mol} \\
\text { substrate) }\end{array}$ & $\begin{array}{c}\mathrm{O}_{2} \text { uptake measured in } \\
\text { Warburg apparatus } \\
\text { [mol } \mathrm{O}_{2} \text { (mol } \\
\text { substrate) }\end{array}$ \\
Acetate & 1.185 & $1.06 \pm 0.09(6)$ \\
Benzoate & 4.955 & $4.92 \pm 0.49(9)$ \\
Fumarate & 1.635 & $1.57 \pm 0.17(3)$ \\
4-Hydroxybenzoate & 4.715 & $4.47 \pm 0.12(11)$ \\
L-Mandelate & 5.875 & $5.84 \pm 0.47(7)$ \\
2-Oxoglutarate & 2.125 & $2.05 \pm 0.21(2)$ \\
Phenylglyoxylate & 5.34 & $5.48 \pm 0.36(4)$ \\
Salicylate & 4.65 & $4.90 \pm 0.41(9)$ \\
Succinate & 2.055 & $1.79 \pm 0.21(4)$
\end{tabular}

The validity of these calculations was checked in two ways. First, the $Y_{\mathrm{O}_{2}}^{\mathrm{gax}}$ value calculated from the $Y_{\text {succinate }}^{\max }$ value of Hardy \& Dawes (1985) was 23.46 (Table 1), in close agreement with the experimental value of 23.15 determined from measurements of $\mathrm{O}_{2}$ uptake (Hardy \& Dawes, 1985). Secondly, results of experiments on $\mathrm{O}_{2}$ uptake by bacterial suspensions in growth media were used to measure total amounts of $\mathrm{O}_{2}$ uptake per mol of substrate (Table 2). These experiments were done for quite different reasons and were used at the time only to measure rates, rather than amounts, of $\mathrm{O}_{2}$ uptake. However, the experimental stoichiometries were in close agreement with the calculated stoichiometries and the largest discrepancy was about $15 \%$.

The calculated amounts of $\mathrm{O}_{2}$ used for respiration, together with the growth yields, were then used to calculate $Y_{\mathrm{O}_{2}}$ values (Table 1). For example in the case of continuous culture on phenylglyoxylate, $Y_{\mathrm{O}_{2}}=$ growth yield/calculated respiratory $\mathrm{O}_{2}$ uptake $=66.5 \mathrm{~g}$ dry wt $(\mathrm{mol}$ phenylglyoxylate $)^{-1} / 3.30 \mathrm{~mol} \mathrm{O}_{2}$ respired $(\mathrm{mol} \text { phenylglyoxylate) })^{-1}=20.15 \mathrm{~g}$ dry wt $(\mathrm{mol}$ $\left.\mathrm{O}_{2}\right)^{-1}$. 


\section{Respiratory efficiency}

The mean of the $Y_{\mathrm{O}_{2}}$ values listed in Table 1 for strain NCIB 8250 is about $19 \mathrm{~g}$ dry wt per mol of $\mathrm{O}_{2}$, which is equivalent to $9.5 \mathrm{~g}$ dry wt per atom of $\mathrm{O}$. This is close to the Bauchop \& Elsden (1960) empirical yield constant of $10.5 \mathrm{~g}$ dry wt per mol of ATP. It is also a little less than the theoretical yields calculated by Stouthamer (1979) for growth on acetate/salts or malate/salts media ( 10.0 and $15.4 \mathrm{~g}$ dry wt per mol ATP respectively). These are probably fair values to assume for strain NCIB 8250 because acetate and malate are representative of the amphibolic products of metabolism of the substrates listed in Table 1. [This strain does not grow on carbohydrates (Fewson, 1967; Baumann et al., 1968) which might be expected to support higher $Y_{A T P}^{\max }$ values (Stouthamer, 1979)]. It is therefore tempting to suggest that there is only a single site of oxidative phosphorylation in strain NCIB 8250. This conclusion appears to be supported by calculations (not shown) of theoretical maximum molar growth yields for continuous culture on L-mandelate assuming one, two or three sites of phosphorylation; the theoretical yields would then be about 69,97 or $111 \mathrm{~g} \mathrm{dry} \mathrm{wt} \mathrm{mol}^{-1}$ respectively. These calculations (based on Table 6 of Stouthamer, 1979) lead to the same conclusions as that drawn by Hardy \& Dawes (1985) for similar calculations based on growth on succinate: the observed yield $\left(70.6 \mathrm{~g}\right.$ dry wt mol$\left.{ }^{-1}\right)$ corresponded closely to the assumption of a single site of phosphorylation. An independent calculation which produced a similar conclusion concerns those substrates which must be oxidized by NAD-dependent dehydrogenases before any of the molecule can enter the amphibolic pathways. Successive pairs of compounds of this sort include benzyl alcohol/benzaldehyde, benzaldehyde/benzoate, 4-hydroxybenzyl alcohol/4-hydroxybenzaldehyde, 4-hydroxybenzaldehyde/4-hydroxybenzoate, 2-hydroxybenzyl alcohol/salicylate (two steps). The average difference in yield for these pairs was $7.3 \mathrm{~g}$ dry weight per $2 \mathrm{H}$, again suggesting that a single site of oxidative phosphorylation is linked to NADH oxidation.

The $Y_{\mathrm{O}_{2}}$ values for succinate were close to the mean of all the $Y_{\mathrm{O}_{2}}$ values and so succinate seems to be a good representative substrate. This apparently validates the generality of the conclusions reached by Hardy \& Dawes (1985). However, this tends to disguise the rather wide range of $Y_{\mathrm{O}_{2}}$ values (Table 1). There were several values of less than 16 or more than 23. This variation suggests that the explanation of a single site of phosphorylation may be too facile. Several reasons for the low and varied yields are possible. (a) The precise balance of amphibolic products probably varies from substrate to substrate and so there will not be a unique value for the theoretical $Y_{\mathrm{ATP}}^{\max }$ (Stouthamer, 1979). (b) Products might accumulate. Some strains of $A$. calcoaceticus form compounds such as emulsifiers (Sar \& Rosenberg, 1983) but probably not under the conditions used in the present study (Rubinovitz et al., 1982). I did not measure Crecovery with all substrates; however, when strain NCIB 8250 was growing in continuous culture on limiting succinate there was no significant accumulation of products (Hardy \& Dawes, 1985). Similarly, benzyl alcohol and benzaldehyde appeared transiently during batch culture on L-mandelate or phenylglyoxylate but they were then oxidized and the final recovery of carbon in $\mathrm{CO}_{2}$ and cells was $100 \pm$ about 5\% (Cook et al., 1975). (c) Catabolism and biosynthesis might be uncoupled and slip reactions could dissipate ATP (Neijssel \& Tempest, 1976; Stouthamer, 1979). (d) Even though the potential P/O ratio might be two or three, very rapid proton decay across the membrane might lead to an actual $\mathrm{P} / \mathrm{O}$ ratio near one, as suggested for Rhizobium leguminosarum by Ratcliffe et al. (1983).

Failure to make use of all the potential synthesis of ATP would be consistent with the conclusions that the redox chain of $A$. calcoaceticus $\mathrm{HO} 1-\mathrm{N}$ is divided into two equivalent sites of energy conservation (Ensley et al., 1981) and that proton translocating loops 0,1 and 2 are active in $A$. Iwoff 4B(Meyer \& Jones, 1973; Jones et al., 1975). Results of experiments to determine $\rightarrow \mathrm{H}^{+} / \mathrm{O}$ quotients all seem to suggest that there are at least two sites of oxidative phosphorylation (Meyer \& Jones, 1973; Jones et al., 1975; Hardy \& Dawes, 1985). This notion is also supported by a consideration of the differences in maximum molar growth yields on L-mandelate and phenylglyoxylate (Table 1). L-Mandelate gave $4.1 \mathrm{~g}$ more dry weight per mol than did phenylglyoxylate $\left(70.6-66.5 \mathrm{~g} \mathrm{dry}^{\mathrm{w}} \mathrm{mol}^{-1}\right)$. This is about half the value for the NAD-linked processes described above. L-Mandelate dehydrogenase is certainly not NAD-linked (Hills \& Fewson, 1983) and may be flavin-dependent (N. Allison, unpublished results). This result 
therefore suggests that (a) flavin oxidation is coupled to phosphorylation and $(b)$ NADH oxidation is coupled to at least two sites. This in turn is consistent with $Y_{\mathrm{A} \text { mp }}^{\text {max }}$ values of around 10 and effective $\mathrm{P} / \mathrm{O}$ ratios of one, even though several sites of phosphorylation may be involved.

\section{Other strains of $A$. calcoaceticus}

Bearing in mind the probable requirements for maintenance, the yields of strains 4B (Jones et al., 1977) and NCIB 8250 growing on DL-lactate were fairly close, as were the yields of strains 4736 (Abbott et al., 1974) and NCIB 8250 growing on ethanol (Table 1). By far the highest $Y_{\mathrm{O}_{2}}^{\text {pax }}$ value for $A$. calcoaceticus appears to be the value of $40 \cdot 8 \mathrm{~g}$ dry wt $\left(\mathrm{mol} \mathrm{O}_{2}\right)^{-1}$ for growth on acetate of the strain used by Du Preez et al. (1981) (Table 1). There is a great spectrum of strains in the species $A$. calcoaceticus (Baumann et al., 1968) but the yield reported by Du Preez et al. (1981) for growth of their strain on ethanol was not proportionately so much greater than that for strains 4736 or NCIB 8250 (Table 1) so it is not possible to dismiss the acetate yield simply as a strain difference. However, the very high yield on acetate arose by extrapolation of data indicating an extremely high maintenance coefficient $\left[7.45 \mathrm{mmol}(\mathrm{g} \text { dry wt})^{-1} \mathrm{~h}^{-1}\right.$; Du Preez et al., 1981]. In reality the highest yield was $25 \cdot 2 \mathrm{~g}^{\mathrm{dry}} \mathrm{wt} \mathrm{mol}^{-1}$ at a growth rate as high as about $1 \mathrm{~h}^{-1}$. This is not so different from the yield of strain NCIB 8250 on acetate in batch culture (Table 1); in addition, the yield of strain NCIB 8250 growing on acetate in continuous culture at 0.2 to $0.3 \mathrm{~h}^{-1}$ was about $18.5 \mathrm{~g}$ dry wt $\mathrm{mol}^{-1}$ (G. A. Hardy, private communication) which compares closely with a yield of about $18 \mathrm{~g}^{\text {dry }}$ wt mol ${ }^{-1}$ at $0.3 \mathrm{~h}^{-1}$ interpolated from the results of Du Preez et al. (1981). It is very unlikely that the $Y_{\mathrm{ATP}}^{\max }$ for growth on acetate would be over $20 \mathrm{~g} \mathrm{dry} \mathrm{wt} \mathrm{mol}^{-1}$ so the results of Du Preez et al. (1981) provide further evidence that at least under some conditions $A$. calcoaceticus has more than one site of phosphorylation. The experimental yields of $A$. calcoaceticus growing on acetate are not too different from those of Escherichia coli, which also has an extremely high maintenance coefficient for acetate (Hempfling \& Mainzer, 1975).

\section{Conclusions}

Growth yields of $A$. calcoaceticus are low. There are various possible explanations for this. The most likely is that the effective $\mathrm{P} / \mathrm{O}$ ratio is only about one under most conditions even though there may be two or more sites of oxidative phosphorylation. Perhaps it is disappointing that an organism which is so metabolically versatile is so inefficient in this respect. This is further evidence that the principal selective pressures operating on bacteria have not tended to maximize yield (Tempest, 1978; Westerhoff et al., 1983).

I am grateful to Professor E. A. Dawes, Dr G. A. Hardy and Dr I. S. Hunter for discussions and to Mrs I. Gall for technical assistance.

\section{REFERENCES}

Aвbott, B. J., Laskin, A. I. \& McCoy, C. J. (1974). Effect of growth rate and nutrient limitation on the composition and biomass yield of Acinetobacter calcoaceticus. Applied Microbiology 28, 58-63.

BAKER, J. (1968). Low cost continuous culture apparatus. Laboratory Practice 17, 817-824.

BAUChOP, T. \& ELSDEN, S. C. (1960). The growth of microorganisms in relation to their energy supply. Journal of General Microbiology 23, 457-469.

Baumann, P. (1968). Isolation of Acinetobacter from soil and water. Journal of Bacteriology 96, 39-42.

Baumann, P., Doudoroff, M. \& Stanier, R. Y. (1968). A study of the Moraxella group. II. Oxidasenegative species (Genus Acinetobacter). Journal of Bacteriology 95, 1520-1541.

BegGS, J. D. \& Fewson, C. A. (1977). Regulation of synthesis of benzyl alcohol dehydrogenase in Acinetohacter calcoaceticus NCIB 8250 . Journal of General Microbiolog. 103, 127-140.
Cook, A. M., Beggs, J. D. \& Fewson, C. A. (1975). Regulation of growth of Acinetobacter calcoaceticus NCIB 8250 on L-mandelate in batch culture. Journal of General Microbiology 91, 325-337.

Dagley, S. (1978). Pathways for the utilization of organic growth substrates. In The Bacteria, vol. VI, pp. 305-388. Edited by L. N. Ornston \& J. R. Sokatch. New York: Academic Press.

Du Preez, J. C., Toerien, D. F. \& Lategan, P. M. (1981). Growth parameters of Acinetobacter calcoaceticus on acetate and ethanol. European Journal of Applied Microbiology and Biotechnology 13, 45-53.

Ensley, B. D., Irwin, R. M., Carreira, L. A., HOFFMAN, P. S., MORGan, T. V. \& FinNERTY, W. R. (1981). Effects of growth substrates and respiratory chain composition on bioenergetics in Acinetobacter sp. strain HO1-N. Journal of Bacteriology 148, 508 513. 
Fewson, C. A. (1967). The growth and metabolic versatility of the Gram-negative bacterium NCIB 8250 ('Vibrio 01'). Journal of General Microbiology 46, 255-266.

HARDY, G. A. \& DAWES, E. A. (1985). Effect of oxygen concentration on the growth and respiratory efficiency of Acinetobacter calcoaceticus. Journal of General Microbiology 131, 855-864.

Hempfling, W. P. \& Mainzer, S. E. (1975). Effects of varying the carbon source limiting growth on yield and maintenance characteristics of Escherichia coli in continuous culture. Journal of Bacteriology 123, 1076-1087.

Hills, C. A. \& Fewson, C. A. (1983). Mutant strains of Acinetobacter calcoaceticus possessing additional mandelate dehydrogenases. Identification and preliminary characterization of the enzymes. Biochemical Journal 209, 379-386.

Jones, C. W., Brice, J. M., Downs, A. J. \& Drozd, J. W. (1975). Bacterial respiration-linked proton translocation and its relationship to respiratorychain composition. European Journal of Biochemistry 52, 265-271.

Jones, C. W., Brice, J. M. \& EdWARds, C. (1977). The effect of respiratory chain composition on the growth efficiencies of aerobic bacteria. Archives of Microbiology 115, 85-93.

Jones, G. L., Jansen, F. \& McKay, A. J. (1973). Substrate inhibition of the growth of bacterium NCIB 8250 by phenol. Journal of General Microbiology 74, 139-148.

Kennedy, S. I. T. \& Fewson, C. A. (1968). Metabolism of mandelate and related compounds by bacterium NCIB 8250. Journal of General Microbiology 53, 259-273.

MeYer, D. J. \& Jones, C. W. (1973). Oxidative phosphorylation in bacteria which contain different cytochrome oxidases. European Journal of Biochemistry 36, 144-151.

Neisssel, O. M. \& TeMPEST, D. W. (1976). The role of energy-spilling reactions in the growth of Klebsiella aerogenes NCTC 418 in aerobic chemostat culture. Archives of Microbiology 110, 305-311.

PIRT, S. J. (1965). The maintenance energy of bacteria in growing cultures. Proceedings of the Royal Society B163, 224-231.
PIRT, S. J. (1982). Maintenance energy: a general model for energy-limited and energy-sufficient growth. Archives of Microbiology 133, 300-302.

Ratcliffe, H. D., Drozd, J. W. \& Bull, A. T. (1983). Growth energetics of Rhizobium leguminosarum in chemostat culture. Journal of General Microbiology 129, 1697-1706.

Rubinovitz, C., Gutnick, D. L. \& Rosenberg, E. (1982). Emulsan production by Acinetobacter calcoaceticus in the presence of chloramphenicol. Journal of Bacteriology 152, 126-132.

SAR, N. \& Rosenberg, E. (1983). Emulsifier production by Acinetobacter calcoaceticus strains. Current Microbiology 9, 309-314.

Slater, J. H. \& Bull, A. T. (1982). Environmental microbiology: biodegradation. Philosophical Transactions of the Royal Society B297, 575-597.

Stouthamer, A. H. (1979). The search for correlation between theoretical and experimental growth yields. In International Reviews of Biochemistry. Microbial Biochemistry, vol. 21, pp. 1-47. Edited by J. R. Quayle. Baltimore: University Park Press.

TEMPEST, D. W. (1978). The biochemical significance of microbial growth yields: a reassessment. Trends in Biochemical Sciences 3, 180-184.

Tempest, D. W., Dicks, J. W. \& Hunter, J. R. (1966). The interrelationships between potassium, magnesium and phosphorus in potassium-limited chemostat cultures of Aerobacter aerogenes. Journal of General Microbiology 45, 135-146.

van Verseveld, H. W., Chesbro, W. R., Braster, M. \& Stouthamer, A. H. (1984). Eubacteria have 3 growth modes keyed to nutrient flow. Consequences for the concept of maintenance and maximal growth yield. Archives of Microbiology 137, 176-184.

WESterhofF, H. V., HellinWERF, K. J. \& VAN Dam, K. (1983). Thermodynamic efficiency of microbial growth is low but optimal for maximal growth rate. Proceedings of the National Academy of Sciences of the United States of America 80, 305-309.

Wilkinson, T. G., Topiwala, H. H. \& Hamer, G. (1974). Interactions in a mixed bacterial population growing on methane in continuous culture. Biotechnology and Bioengineering 16, 41-59. 